\title{
The Political Heart of China's Exclusionary Rule of Illegally Obtained Evidence: A Comparative Study with the International Criminal Court
}

\author{
Luye Mou*
}

Article 69(7) of the International Criminal Court Statute develops a specific rule to exclude evidence and thus ensure evidentiary reliability and procedural integrity before its proceedings. China has introduced the exclusionary rule of illegally obtained evidence that places an overriding priority on pursuing factual accuracy, because the rule has been devised and applied primarily for the sake of preventing miscarriages of justice and bolstering governmental integrity. A political imperative for truth makes the rule incompatible with the existing institutional environment. The ICC's rule and practice illuminates the importance of neither assuming the excellence of the rule nor borrowing the rule without modification, but of exploring the rule that is based upon one's own practical experience, institutional structure, and political powers. This article embraces the room for flexibility, experimentation, and adaptation that can contribute to a healthy scheme for legal transplant and law reform.

\section{Keywords}

International Criminal Court, Exclusionary Rule, Miscarriages of Justice, Legal Transplant, Procedural Integrity 


\section{Introduction}

Comparative law is useful to provide additional knowledge about other legal possibilities, avoid mistakes or adopt better solutions in practice elsewhere, and improve understanding of the system we have been educated and trained in. ${ }^{1}$ This comparative approach to recent developments in both the International Criminal Court (ICC) and China focuses on the topic of "illegally obtained evidence," which is of equal significance for the criminal proceedings before both international and domestic criminal courts. It deserves prompt attention for the three specific reasons.

Firstly, this topic has resurfaced in the ICC and China as a result of legislation. Different from the International Criminal Tribunals for former Yugoslavia and Rwanda, ${ }^{2}$ which were governed by flexible and broad rules of procedure and evidence, the ICC proceedings are regulated by detailed provisions contained in the ICC Statute and the Rules of Procedure and Evidence that have provided a fuller procedural scheme. ${ }^{3}$ Nowadays, legal systems plagued by common goals of accurate fact-finding, effective rights protection, and controlling serious crimes are seeking foreign solutions to similar problems. ${ }^{4}$ As for China, the exclusionary rule of illegally obtained evidence was first promulgated in 2010 in an attempt to guarantee factual accuracy and avoid miscarriages of justice. Ever since, the rule has been propagated continuously and improved in many top-level documents. ${ }^{5}$ This was culminated in the 2017 Rules of Strict Exclusion of the Illegally Obtained Evidence (hereinafter 2017 Exclusionary Rule). ${ }^{6}$

Secondly, the exclusionary rule of illegally obtained evidence has been studied extensively in China, but this has largely been in the American and European context.

1 J. Nijboer, Methods of Investigation and Exclusion of Evidence, in HaRmonizATION IN Forensic EXPERTISE 431-46 (J. Nijboer \& W. Sprangers eds., 2000).

2 In this article, the ICTY and the ICTR are referred to as "ad hoc tribunals."

3 The ICC Statute (or the Rome Statute) is the international treaty adopted at Rome in 1998. The ICC Rules of Procedure and Evidence (ICC Rules) was agreed on in the Preparatory Commission in November 2000 and formally adopted by the first Assembly of State Parties in September 2002. The ICC Rules constitute a full-fledged body of procedural provisions that cover nine parts of the ICC Statute.

4 J. Jackson, The Effect of Human Rights on Criminal Evidentiary Process: Towards Convergence, Divergence or Realignment, 68 Mod. L. Rev. 737-64 (2005).

5 E.g., Opinions on Advancing the Reform of the Trial-centered Criminal Procedure System [关于推进以审判为中心的 刑事诉讼制度改革的意见] (promulgated by the Supreme People's Court (SPC), the Supreme People's Procuratorate (SPP) and the Ministry of Public Security (MPS), Aug. 3, 2016), arts. 4-5.

6 Provisions on the Several Issues concerning the Strict Exclusion of the Illegally Collected Evidence in the Handling of Criminal Cases [关于办理刑事案件严格排除非法证据若干问题的规定] (promulgated by the SPC, SPP and MPS, June 20, 2017). 
The ICC's legislation and practice relating to illegally obtained evidence have attracted scant judicial and academic attention, resulting in failure to learn lessons from an international juridical body that is "resolved to guarantee lasting respect for and the enforcement of international justice." Moreover, investigating the legislation and practice in the ICC and China can add a few brush strokes to re-envisioning the global profusion of exclusionary rule and the trend of legal convergence between the common law and civil law systems. Particular consideration needs to be given to the risk that one imported evidentiary doctrine may alter its character in interaction with the new environment. ${ }^{8}$

Thirdly, criminal procedure has been characterized as a seismograph of the rule of law, ${ }^{9}$ and the debate over the exclusionary rule can highlight the competing aspects of the rule of law: crime control and due process. Whether to exclude evidence requires reconciling and balancing competing values that have far-reaching legal and political implications. The topic of illegally obtained evidence cannot be analyzed satisfactorily only within a narrow evidentiary framework. To describe the broader legal settings in which the exclusionary rule works helps uncover a political face of the rule. For most practical purposes, the application and improvement of the rule can be fitted under that face.

This article aims to study the exclusionary rule in the context of legal convergence. It is, however, not to pinpoint the ICC and China on the common law or the civil law spectrum. As that dichotomy may not always prove a useful framework for describing the complexity of real-life processes, ${ }^{10}$ I would intend to ascribe features on an empirical basis from what is happening in the ICC and China, and to survey and compare their attempts to fashion evidentiary rules across different legal traditions. Admittedly, my examination of the exclusionary rule is not contemplated to be exhaustive. Rather, considerations of the rule across main jurisdictions will be taken only in general terms to highlight differences in the underlying rationale(s) of exclusion, which is attendant to the interests expressed in their institutional and political arrangements.

In this article, after a brief Introduction, Part two examines the ICC's exclusionary rule of illegally obtained evidence, in addition to its normative strength and functional performance. The convergence and divergence from the common law

7 ICC Statute, pmbl. § 11.

8 M. Damaška, The Uncertain Fate of Evidentiary Transplants, 45 Aм. J. CoмP. L. 839-52 (1997).

9 J. Herrmann, Chinese Criminal Procedure Reform of 2012 How Much Reform Did It Bring, 1 PekING U. L. J. 163-79 (2013).

10 K. Ambos, International Criminal Procedure: Adversarial, Inquisitorial or Mixed, 3 INT'L CRIM. L. Rev. 1-38 (2003). 
and civil law approaches deserve special attention, as both help re-evaluate China's exclusionary rule as a sort of legal transplant. Part three situates China's reform within the comparative literature of the exclusionary rule in general, and, in particular, explores the motivation behind the push in China to invigorate the previously scattered provisions addressing the legality of evidence. By observing the rule in a broader context of top-level designed reforms initiated around the year of $2012{ }^{11}$ this part seeks to reveal an instrumental and pragmatic idea of legal transplant that underpins the criminal justice reform in China. The exclusionary rule has been advocated, introduced, and applied primarily for political concerns: to avoid miscarriages of justice and preserve the government's performance-based legitimacy. With this political heart at its core, the weaknesses of China's exclusionary rule will be identified in Part four. I will present four examples to make comparisons with the ICC's rule and practice. The concluding Part calls for a cautious attitude toward risks of unwarranted legal transplant and puts forward some potential solutions to those problems. In the coming years we will see continuous and far-reaching legal integration in the international community. ${ }^{12}$ Only a global approach to research and a broad set of structural reforms hold real promise.

\section{Exclusionary Rule of Illegally Obtained Evidence at the ICC}

Common law system is characterized by an exclusionary approach to evidence that is designed to prevent fact-finders from becoming contaminated by unduly prejudicial evidence. ${ }^{13}$ Exclusionary rules, long associated with common law, have mushroomed over the last few decades in continental criminal procedures. This is motivated by the concern that the search for the truth should proceed in socially acceptable ways. ${ }^{14}$ From a global perspective, some commentators have detected a gradual convergence in the evidentiary process of common law and civil law systems. ${ }^{15}$ In the context of international criminal justice, drafters of the ICC's legal framework have established

11 Around 2012, the policymaking context changed in favor of drastic departures as the CCP realized that China had entered a "deep water" zone and could no longer afford to "grope the stone to cross the river." Improvised reform gave way to a more methodical and profound set of changes.

12 See generally J. Jackson \& S. Summers, The Internationalisation of Criminal Evidence (2012).

13 Id. at 368.

14 M. Damaška, Free Proof and its Detractor, 43 Aм. J. Comp. L. $343-58$ (1995).

15 JACKSON \& SUMMERS, supra note 12, at 6. 
a system sui generis that does not favor any existing legal family. Rather, it is a true hybrid procedure that blends rules emanating from both common law and civil law systems. At the outset, it must be noted that neither the ICC Statute nor the Rules explicitly uses the expression "illegally obtained evidence." Article 69(7) of the ICC Statute develops a specific exclusionary rule for evidence, reading as follows:

\begin{abstract}
Evidence obtained by means of a violation of this Statute or internationally recognized human rights shall not be admissible if: a. the violation casts substantial doubt on the reliability of the evidence; or b. the admission of the evidence would be antithetical to and would seriously damage the integrity of the proceedings. [Emphasis added]
\end{abstract}

Violating either the statute or internationally recognized human rights is a prerequisite for excluding evidence. However, exclusion will not be triggered automatically unless the evidence obtained otherwise than in compliance with internationally recognized human rights standards is potentially unreliable or would undermine the proceedings. ${ }^{16}$ At first glance, Article 69(7) is formulated as a mandatory exclusionary rule, but both the ICC Statute and the Rules are silent as to the specific situations regulated by sub-provisions (a)(b). Their wording contains several vague terms, such as reliability and integrity, whose interpretation requires the exercise of evaluation and discretion of the judge. In this sense, sub-provisions (a)(b) have reshaped Article 69(7) into a discretionary exclusionary rule. This has already been confirmed in the case of Lubanga, which claims: "Article 69(7) of the ICC Statute rejects the notion that evidence procured in violation of internationally recognized human rights should be automatically excluded." ${ }^{\prime 17}$ In accordance with the discretionary nature of Article 69(7)'s exclusion, the court should consider various factors in combination with concrete facts of the specific case and balance conflicting interests relating to the rationales behind evidentiary exclusion. Two factors explicitly mentioned here are 'reliability' and 'integrity.'

The reliability rationale does not leave much room for doubt in the ICC or other jurisdictions. In England and Wales, Section 76(2) of the 1984 Police and Criminal Evidence Act forbids admitting confessions obtained in consequence of anything said or done that is likely to render any confession unreliable. Evidentiary reliability is important because unreliable evidence is not conducive to accurate fact-finding or the

16 Prosecutor v. Lubanga, ICC-01/04-01/06, Decision on the admission of material from the "bar table," ICC Trial Chamber I, June 24, 2009, § 37, https://www.icc-cpi.int/CourtRecords/CR2009_04726.PDF.

17 Prosecutor v. Lubanga, ICC-01/04-01/06, Decision of the confirmation of charges, ICC Pre-Trial Chamber I, Jan. 29, 2007, § 84, https://www.icc-cpi.int/CourtRecords/CR2007_02360.PDF. 
minimization of errors in adjudication. ${ }^{18}$ Though some argue that the search for the truth is the most significant goal of the ICC proceedings, ${ }^{19}$ either reliability or truth always and in every context would not enjoy lexical priority over the other values involved in the criminal process and exclusionary rule. ${ }^{20}$

Different jurisdictions, may have different ways to achieve truth. However, there is a consensus that the truth should not be sought at any price. ${ }^{21}$ One may also argue that the test of reliability seems redundant, because unreliable evidence will not be admitted, regardless of how it is collected. Seen in this light, Article 69(7)(a) essentially requires the court to evaluate the hypothetical reliability that violations might cast doubt on, rather than the unreliability that violations have already caused. $^{22}$ In any case, assessing the evidentiary reliability needs case-specific inquiries from the vantage point of hindsight.

The sub-provision (b) introduces another aim that the exclusionary rule endeavors to achieve 'integrity.' In the US, with the rationale of deterrence recognized increasingly as the sole benefit of the exclusionary rule, the integrity rationale is being downplayed and completely subsumed within the deterrent effect. ${ }^{23}$ By contrast, Article 24(2) of the Canadian Charter of Rights and Freedoms requires excluding evidence if admitting it would bring the administration of justice into disrepute. In Grant, the term, "bring the administration of justice into disrepute," has been interpreted in the long-term sense of maintaining the integrity of the justice system. ${ }^{24}$ Throughout the world, the constitutional ideas of Canada are more influential than those of the US, largely because Canada is seen as reflecting emerging international consensus. ${ }^{25}$

Such emerging consensus relating to the integrity rationale has been promoted zealously by two leading evidence scholars, Adrian Zuckerman and Ian Dennis, who articulate that illegally obtained evidence cannot be admitted to help in the pursuit of the truth, because truth-finding is merely a 'means' and the ultimate goal of criminal

18 The overriding objective of the Criminal Procedure Rules 2015 in England and Wales is exactly "acquitting the innocent and convicting the guilty." See The 2015 Criminal Procedure Rules, § 1.1.2.

19 R. May \& M. Wierda, International Criminal Evidence 14 (2002).

20 P. Roberts \& A. Zuckerman, Criminal Evidence 180 (2d. ed. 2010).

21 T. Weigend, Is the Criminal Process about Truth: A German Perspective, 26 Harv. J. L. \& PuB. PoL'y 157-74 (2003).

22 A. Ashworth \& M. Redmayne, The Criminal Process 109-10 (4th ed. 2010).

23 R. Bloom \& D. Fentin, A More Majestic Conception: The Importance of Judicial Integrity in Preserving the Exclusionary Rule, 13 U. PA. J. Const. L. 47-80 (2010-11).

24 R v. Grant, Supreme Court of Canada, [2009] 2. S. C. R. 353, § 68.

25 F. Schauer, The Politics and Incentives of Legal Transplantation, in Governance IN A Globalizing World 253-68 (J. Nye \& J. Donahue eds., 2000). 
trials is to preserve its "moral dimension." 26 Though the integrity rationale has been somewhat criticized for indeterminacy and lack of clarity, the merits of admitting or excluding evidence are too complex to be reduced to any simple, all-purpose rule. ${ }^{27}$ Before the ICC's proceedings, the respect for the integrity is necessarily made up of respect for the core values that run through the ICC Statute. ${ }^{28}$ Applying Article 69(7)(b) involves a discretionary weighing of such values as the respect for a state's sovereignty, respect for human rights, protection of witnesses and victims, and the successful bringing to justice of perpetrators of serious crimes.

Article 69(7) must be considered in relation to Article 64 of the ICC Statute, ruling on the relevance or admissibility of the evidence. The Lubanga case clearly states that Article 69(7) is lex specialis to other rules on admissibility that the ICC's Statute and the Rules have adopted a flexible approach to regulate. Along with the "flexibility principle" developed at the ad hoc tribunals, an open approach to admissibility of evidence before the ICC tribunals is primarily due to the composition of the tribunals, because fact-finders in those proceedings are not a lay jury but professional judges.

Notwithstanding a threshold concept of admissibility, the ICC Statute and the Rules allow evidence into trial more readily and only later asks the court to attach appropriate weight to it. Likewise, Article 69(7) incorporates an exclusionary rule that represents a remarkable character of common law tradition, but, at the same time, calls for discretionary evaluation akin to the principle of free evaluation in the civil law system. In this sense, the ICC's evidentiary rules appear to lend credence to the convergence trend between different legal families.

Another reason for embracing such a hybrid rule lies in the fact that evidentiary rules are shaped not just by principles of fair trial and the rights of the accused, but also by what is possible under the circumstances. ${ }^{29}$ Credible evidence can be hard to come by because states may not cooperate in investigation, because witnesses may fear retaliation for their testimony, and time elapses between the crimes and trials. The more difficult it is to collect evidence, the broader the range of evidence the court will need to ensure the sufficiency of evidence and reach the level beyond a reasonable doubt. Such need is even greater if we remember the initial experience of the ICC that reminds us how it was difficult to obtain evidence for its judicial

26 I. Dennis, The Law of Evidence 238-9 (6th ed. 2017). See generally A. Zuckerman, The Principles of Criminal EVIDENCE 344 (1989).

27 Roberts \& ZuCKerman, supra note 20, at 190.

28 Lubanga case, supra note $16, \S 42$.

29 A. Whiting, The ICTY as a Laboratory of International Criminal Procedure, in THE LEGACY of THE InTERNATIONAL Criminal Tribunal for the Former Yugoslavia 83-107 (B. Swart et al. eds., 2011). 
activities. ${ }^{30}$ In short, the complex factual situations, the large amount of evidence, and the difficulties in obtaining that evidence, are all contributing factors to a flexible and liberal regime of admissibility.

As procedural and evidentiary rules only provide for a general framework, its smooth functioning depends ultimately upon the legal actors, especially the judges. In the early days of ad hoc tribunals, the procedural solutions and revisions were devised by judges themselves, who were acting not as theorists seeking to impose an overarching system on the rules but rather as participants trying to devise pragmatic solutions to specific challenges that arose in particular cases. ${ }^{31}$ In view of the discretion afforded by Articles 64 and 69 of the ICC Statute, judges are charged with the general responsibility of upholding high standards of moral integrity in criminal proceedings.

As the topic of exclusionary rule lies in tension between two poles, i.e., due process and crime control, the integrity rationale demands a balancing approach in consideration of moral values, policy objectives, and pragmatic constraints embodied in due process and crime control. In this vein, the balancing approach might be criticized for indeterminacy and incoherence. However, the truth is that, in almost all legal systems, the categorical exclusions of illegally obtained evidence are often not fully enforced. ${ }^{32}$ For example, the US experience has shown that an inflexible rule of exclusion cannot encompass the diversity of human activities, and the US Supreme Court has recognized many exceptions to the judicially-created exclusionary rule. ${ }^{33}$ Therefore, a contextual and fact-sensitive approach to discretionary exclusion is both defensible and sound. The key problem here is how to guide the exercise of discretion in a reasonable manner. One method of minimizing the inherent difficulties in the exercise of discretionary power is to indicate precisely the nature of conflicting interests that should be balanced and articulate the factors. In this case, the conflicting interest should be taken into account in the exercise of discretion.

Before leaving the ICC's exclusionary rule, the broader structure embedded in it needs to be highlighted. We have seen that the ICC's evidence law constitute

30 S. de Gurmendi, The Challenges of the International Criminal Court, in Essays on International Criminal Justice 194-8 (H. Olasolo ed., 2012).

31 G. Boas, Admissibility of Evidence under the Rules of Procedure and Evidence of the ICTY: Development of the "Flexibility Principle," in Essays on ICTY Procedure and Evidence in Honour of Gabrielle Kirk McDonald 273-4 (R. May et al. eds., 2001).

32 Herrmann, supra note 9, at 167.

33 For example, Wong Sun v. United States, 371 U.S. 471 (1963) (attenuation exception); United States v. Leon, 468 U.S. 897 (1984) (good faith exception); Missouri v. Seibert, 542 U.S. 600 (2004) (Miranda warning exception). 
a unique amalgam. It is not the superiority of either the ideal or the model that determines the drafters' choice, but the fact that the amalgam can escape a rigid assumption about the dichotomy of common law and civil law systems. In other words, important is not whether a rule is borrowed from either common law or civil law jurisdiction, but whether it assists the ICC tribunals to accomplish their tasks and whether it complies with fundamental fair trial standards. ${ }^{34}$ Flexibility offers room to explore a model of the ICC's own features. And, in practice, a promising hybrid is emerging from experiences provided by the hearings and trials in which legal actors from different legal traditions are interacting. Conversely, any blind embrace of celebrated procedural practice in other jurisdictions may run the risk of leaving us with an impoverished understanding of not only the ICC's own model, but also the complexity of legal transplant and development in the historical and international grids.

\section{China's Exclusionary Rule and its Political Heart}

This Part begins with examining China's exclusionary rule of illegally obtained evidence and then explores its purposes and functions. An appreciation for the much broader aspirations will help demonstrate why the exclusionary rule of the AngloAmerican style has been adopted in the inquisitorial-oriented system in China. After briefing the rationales of exclusion, the unique one that China has placed a priority upon can be highlighted: reliability (more precisely, truth). All of these analyses lay a foundation for the subsequent discussions about specific weaknesses of the rule and its tension with other rules and institutions.

The Chinese government has acknowledged officially that coerced confessions are a significant problem in its criminal justice system. ${ }^{35}$ In 2010 , the exclusionary rule was established originally in the form of judicial interpretations issued by the Supreme People's Court (SPC) and other central organs. ${ }^{36}$ Two years later, the rule was absorbed into the revised Criminal Procedure Law (CPL) that provided a basic structure for determining the legality of disputed evidence.

34 Ambos, supra note 10, at 35.

35 I. Belkin, China's Torturous Path toward Ending Torture in Criminal Investigation, 24 Colum. J. Asian L. 273-302 (2010).

36 Provisions on Several Issues Concerning the Exclusion of Illegal Evidence in Criminal Cases [关于办理刑事案件排除 非法证据若干问题的规定] (promulgated by the SPC, SPP and MPS, June 13, 2010; came into effect on July 1, 2010). 
Ever since the year of 2014, China has initiated trial-centered reform in the criminal justice field, and the exclusionary rule has been emphasized repeatedly as an important mechanism of supervising investigators' conduct. ${ }^{37}$ From the fact that the previous legislation does not provide clear and readily applicable guidance to implement the rule, the SPC and other central organs promulgated the 2017 Exclusionary Rule to improve the enforcing mechanisms in many aspects. ${ }^{38}$

The growth of the exclusionary rule does not occur in a vacuum. Over the years, a series of highly publicized wrongful convictions have placed intense pressure on the Chinese government to take action. ${ }^{39}$ Accidentally, Zhao Zuohai's case of the returned 'murdered' victim acts as a catalyst for releasing the rule, ${ }^{40}$ because this case caps a growing tide of concern for miscarriages of justice relating to police misconduct. ${ }^{41}$ After extensive study of the exclusionary rule in other jurisdictions, Chinese scholars and judicial officers have reached a consensus that coerced confession is one of the leading causes for wrongful convictions. Accordingly, the exclusionary rule is expected to regulate the interrogation and ensure the veracity of confession.

Article 56 of the CPL contains two sorts of exclusion: categorical and discretionary. Article 56(1) stipulates that a confession obtained by torture or other illegal means must, without exception, be excluded. As Article 69(7) of the ICC Statute, Article 56(1) contains some ambiguities and leaves considerable discretion to judges for determining whether police misconduct reaches the level of torture, or constitutes threat, enticement, deceit or other illegal means. The evidentiary exclusion found in Article 56(2) seems to be relative or discretionary, because it provides that physical and documentary evidence must be excluded only if it is gathered in a way that may seriously affect justice. Of these two sorts of exclusion, the categorical one is of particular importance, as it is utilized to solve the aforementioned issue in China, namely, wrongful convictions resulting from untruthful confessions obtained

37 Jianwei Zhang, Trial-centeredness Doctrine: Material Connotations and Methods to Accomplish, 4 PekING U. L. J. 101-24 (2016).

38 The 2017 Exclusionary Rule, supra note 6.

39 M. Lewis, Controlling Abuse to Maintain Control: The Exclusionary Rule in China, 43 N.Y.U. J. InT'L L. \& PoL. 62998 (2010).

40 ZHAO Zuohai was forced to confess and convicted of murdering his neighbor, ZHAO Zhenxiang, and was sentenced to death penalty with two years suspension in December 2002. Actually, ZHAO Zhenxiang had a fight with ZHAO Zuohai and injured ZHAO Zuohai's head. In fear of ZHAO Zuohai's retaliation, ZHAO Zhenxiang packed up and rode away on his bicycle immediately after that day. As he lacked the money to treat his hemiplegia in 2009, ZHAO Zhenxiang returned to the village in April 2010, when Zhao Zuohai had been imprisoned for over seven years. See Yanyou Yi, Exclusionary Rules in China, 29 Colum. J. Asian L. 1-69 (2015).

41 Shiyuan Huang, Chinese Wrongful Convictions: Causes and Prevention, 80 U. CIN. L. Rev. 1219-44 (2012). 
through torture. $^{42}$

As to the rationale(s) behind exclusion as laid down in Article 56, the evidentiary reliability plays a dominant role in both normative and practical dimensions. Firstly, avoiding miscarriages of justice is deemed as the first and decisive reason for adopting the rule. Such priority over other justifications, including deterrence, remedy, and integrity, ${ }^{43}$ reflects the government's exclusive attention to reliable confessions and accurate fact-finding. Physical and documentary evidence, in contrast, are said to be more objective in nature, and violations of statutory procedure usually does not damage their reliability. As a result, they are subject to the discretionary exclusion pursuant to Article 56(2). Comparison between the rationales of excluding confessions and real evidence manifests the pivotal role of evidentiary reliability embodied in Article 56.

Secondly, informed by my observation and informal talks with many judges, excluding unreliable confessions and ensuring correct convictions are the key motivations to invoking Article 56 in individual cases. What surprises me most is the phenomenon that, in some cases, Article 56 has been invoked to exclude not only illegally evidence but also expert opinions, testimonies, or video-tapes that the court deems either unreliable or untruthful. Article 56 is becoming an all-encompassing rule for excluding any evidence whose legality, reliability, or probative value is in doubt. One possible way to monitor the abuse of power is to require provision of a reasoned opinion. However, even if the appellate court may scrutinize the reason for exclusion, it remains debatable whether the duty to provide a reasoned verdict can really be said to restrict judges' preference for truth. They may make what seems to them to be the best all-things-considered decision, using the exclusionary rule as ex post rationalization rather than as being genuinely decision motivating or decision guiding. ${ }^{44}$ So, it is fair to say that evidentiary reliability and factual accuracy are indeed the decisive considerations in formulating and using the exclusionary rule.

The ICC's rules and cases acknowledge explicitly that unreliable confessions extracted by illegal or improper means are inadmissible. Why does China camouflage her preference for the reliability rationale? The answer brings us to the core question about the values that the Chinese government is seeking to embody in the rule and, more broadly, the entire criminal justice system. Diane Amann argues that convergence of legal development will be impaired if the state believes that adopting

42 Yi, supra note 40 , at 15-16.

43 Space limitations require that I confine myself to examining only the rationales adopted in the ICC's Statute and Rules and the one (deterrence) that is highly controversial in comparative studies.

44 F. Schauer, On the Supposed Jury-Dependence of Evidence Law, 155 U. PA. L. REv. 165-202 (2006). 
foreign rules will threaten the state's own security position. ${ }^{45}$ To adopt the AngloAmerican exclusionary rule indicates nothing more than the Chinese government's concern about its own legitimacy and security. ${ }^{46}$ It also reveals deep forces that have coalesced to create a receptive atmosphere for reform. The aforementioned goal of safeguarding evidentiary reliability is not a standalone rationale. Rather, it is intertwined with another goal of bolstering the integrity of the government.

China's high-ranking leaders show growing awareness of the danger of hitching the legitimacy and longevity of the government to an economic engine whose velocity is slowing. ${ }^{47}$ The criminal justice reform is one of the flurries of government regulations and initiatives intended to redress many of the social ills and grievances. ${ }^{48}$ Keeping the government responsive to a public aghast over miscarriages of justice, the integrity rationale of evidentiary exclusion should be better interpreted to enhance the "governmental integrity." 49 This understanding can gain support from the official speech delivered by Zhang Jun, who was the ex-vice-president of the SPC and is now the procurator-general of the SPP. He said that, when the Phoenix played the video and showed the interview of Zhao Zuohai, his wrongful conviction was really defaming our judicial authority's reputation and degrading our country's image. ${ }^{50}$ Zhao's case was particularly devastating around 2010, when the intense and widespread propaganda of "constructing a harmonious society" was reaching a peak, as his torture and wrongful conviction were obviously inharmonious features of the era.

Chinese government's attitude toward the exclusionary rule resonates with that of the self-strengthening movement of a century ago: China was to be the 'essence,' while foreign learning was a mere 'instrument.' [中体西用] This essence-instrument logic becomes more evident if we place the exclusionary rule and the entire criminal justice reform into a broader context of top-level designed reforms. In a top-down manner, the exclusionary rule and other reforms have been initiated and tested in piloted courts. Meanwhile, local problems and experience are fed back to central decision-makers. Through interactions between central policy-making and local experimentation, the government can rapidly resolve social conflicts and effectively

\footnotetext{
45 D. Amann, Harmonic Convergence: Constitutional Criminal Procedure in an International Context, 75 IND. L. J. 80974 (2000).

46 The litany of miscarriages of justice was increasingly seen as a blight on the political system as well as the justice system. Therefore, building credibility into the systems made the prevention of miscarriages of justice a political issue.

47 E. Perry, Growing Pains: Challenges for a Rising China, 143 DÆdalus 5-13 (2014).

48 Id.

49 Lewis, supra note 38 , at 635.

50 Yi, supra note 40, at 14.
} 
maintain social stability. ${ }^{51}$

The government's concern is not whether a certain procedural device comes from the common law or the civil law system, but rather whether it would be a helpful tool in the hands of courts, in the sense that the exclusionary rule can bolster its performance-based legitimacy. Once Beijing's preference or keynote appears to be fixed firmly, it becomes irrelevant for local courts to consider where the exclusionary rule has been transplanted or what kind of rationale(s) should undergird the rule. They have every incentive to popularize the exclusionary rule as swiftly as possible, because compliance and conformity constitute the ultimate criterion for career advancement. ${ }^{52}$ The gap between the narrow legal instrumentalism and the very different attitude toward the exclusionary rule, which are of constitutional and human rights significance in other jurisdictions, makes the rule merely a means to desired ends.

\section{China's Exclusionary Rule Revisited: The Problem of Legal Transplant}

The CPL revision was influenced by a political will and a public consensus to place increasing emphasis on protecting individual rights. In the heart of the exclusionary rule, however, preventing wrongful convictions, rather than protecting every citizen's constitutional rights, is playing a more significant role. ${ }^{53}$ The legitimacy of the criminal procedure has also been re-directed to the governmental integrity. Disparities between the ideal and reality bespeak an instrumental concept of legal transplant: to assuage a public aghast over miscarriages of justice and bolster performance-based legitimacy, rather than to achieve legality, fairness or rights protection. More now needs to be said as to what rationales or goals should underpin the exclusionary rule.

If one does not know to which port the boat is sailing, no wind is favorable. As Damaška has noted, the functions that the ICC has sought to fulfill are extensive:

At various times, the courts have expressed their intention to produce a reliable historical record of the context of international crime, to provide a venue for giving

51 B. Liebman, Legal Reform: China 's Law-Stability Paradox, 143 DÆdalus 96-109 (2014).

52 Hualin Fu, Building Judicial Integrity in China, 39 Hastings Int'L \& Comp. L. Rev. 167-82 (2016).

$53 \mathrm{Yi}$, supra note 40 , at 5. 
voice to international crime's many victims, and to propagate human rights values. Courts have also expressed their aspiration to make advances in international criminal law, and to achieve objectives related to peace and security-such as stopping an ongoing conflict-that are far removed from the normal concerns of national criminal justice. $^{54}$

Problems of setting these ambitious goals lie in its overly demanding agenda, incoherence between different goals and lack of a clear sense of their relative weight. ${ }^{55}$ Accordingly, Damaška suggests selecting one central goal and providing argumentative advantage in balancing competing goals. ${ }^{56}$ In assessing the effectiveness of China's exclusionary rule, the starting point has to be the rationale of the rule itself. According to the official speeches of one of the CCP's top-level leaders and other senior judges from the SPC, ${ }^{57}$ legislative objectives of Article 56 include guaranteeing quality in handling cases, punishing crimes, protecting human rights, and upholding justice in accordance with the law. These objectives seem to be of equal importance, but, as indicated above, the rule has been designed and applied primarily as an instrument of pursuing truth, and other rationales or goals are actually subordinate.

Deterrence is the often-cited but controversial rationale. The ad hoc tribunals have made it clear that the domestic exclusionary rule should play a deterrent role, but it is not the tribunals' duty to discipline law enforcement officials. ${ }^{58}$ As to domestic jurisdictions, Time and Dai claim that China's exclusionary rule is undoubtedly intended to deter police work that deviates from required standard and ethical procedures. ${ }^{59}$ Their argument would be strong in the American context, as the US Supreme Court is emphasizing increasingly that the main function of the rule is to deter abusive police practice. ${ }^{60}$ However, what the Chinese government is trying to deter are violations that may cause wrongful convictions or jeopardize factual accuracy, which is not those of constitutional rights or notions of procedural justice. In other words, it is the evidentiary reliability and factual accuracy that make the deterrent effect meaningful.

54 M. Damaška, What is the Point of International Criminal Justice, 83 CHI.-Kent L. Rev. 329-68 (2008). [Emphasis added]

55 M. Damaška, Problematic Features of International Criminal Procedure, in The OXFord Companion to InTERNATIONAL Criminal Justice 175-86 (A. Cassese eds., 2009).

56 Id. at 183.

57 Belkin, supra note 35, at 287.

58 Prosecutor v. Brđanin, No. IT-99-36-T, Decision on the Defense “Objection to Intercept Evidence,” Oct. 3, 2003, § 63(9).

59 V. Time \& M. Dai, Is There Room for Optimism in China's 2010 Exclusionary Rule and Its 2012 Revision, 11 AsIAN CRiminology 21-31 (2016).

60 S. Schulhofer, More Essential than Ever: The Fourth Amendment in the Twenty-First Century 66-7 (2012). 
It is worth revisiting Damaška's concern about the overabundance of the ICC's goals. Overly-ambitious adoption of foreign rules may lead to ineffective laws and even trigger the backfire effect. With an overriding priority to secure truth-finding, it leaves little room to achieve fairness or rights protection. Disparities between aspiration and reality may eventually weaken the respect for law and impair the reputation and legitimacy of the court and the government. Presumably, even if the aforementioned legislative goals of Article 56 do not prioritize truth over other goals, to tell judges to consider rationales of reliability, integrity, and deterrence in an undifferentiated way is to tell them nothing. They are unable to attach appropriate weight to each of them and reach acceptable trade-offs. Absence of clear guidance regarding how to exercise the discretion creates more problems than the rule solves.

Rationales of exclusion extend beyond the specification of fundamental values to inform the more concentrated tasks of designing institutions and procedures capable of serving those values and implementing legislative objectives. But driven by political motivations, the implantation of Anglo-American exclusionary rule into the Chinese soil cannot find its roots in a corresponding institutional environment. Máximo Langer reminds that, even if reformers try to imitate a legal idea or practice, the idea may still be transformed by the structure of meaning, systems of incentives, power arrangements, and individual disposition. ${ }^{61}$ Through the lens of his analytic framework, in what follows, I will present four examples to identify the weaknesses of China's exclusionary rule and its tension with other rules and institutions.

\section{A. The Privilege against Self-incrimination without a Supportive Environment}

Article 55(1)(2) of the ICC Statute recognizes explicitly that the accused shall enjoy the privilege against self-incrimination and the right to remain silent. By contrast, China never affords an accused the right to silence. The 2012 CPL amendment introduces the privilege against self-incrimination, but the accused remains subject to intense interrogations and must answer the police's questions truthfully. ${ }^{62}$ As confessions play a critical role in the bill of charge and final fact-findings in the courtroom, it is extremely difficult to decrease the police's zealousness for obtaining them. Moreover, under the influence of a long-standing policy, "leniency to confessors, severity to resisters," the accused is encouraged to confess at the early stages of criminal proceedings. The criminal process is sequential in nature: a decision made

61 M. Langer, From Legal Transplant to Legal Translation, 45 HaRv. INT'L L. J. 1-64 (2004).

622018 CPL art. 20. 
at the early stages affects decision-makers downstream. As such, even if involuntary confessions were excluded, the fact that the accused has confessed will make it difficult for lawyers to argue for innocence. In other words, involuntary confessions obtained upstream will have an inevitable effect on the quality of decision-making downstream.

What makes it worse is a newly established fast-track sentencing procedure in which the accused can consider to accept both the charge and sentencing in exchange for leniency. Beside the stick approach of "severity to resisters," the Chinese government is now offering considerable concessions as a carrot reward at the pretrial stages. The accused may become unwilling to risk the much higher penalties that might result if $\mathrm{s} /$ he refuses to cooperate and is convicted after trial. Some scholars in the US have found that the practice of plea bargaining has made many constitutional claims "essentially invisible" or has even pushed the accused to offer 'voluntary' false confessions. ${ }^{63}$ Based upon my analysis of 269 cases, where the defendants have confessed to being guilty, accepted the punishments, and agreed to be heard by the fast-track sentencing procedure, eleven of them appealed to higher courts and challenged the voluntariness of confessions. None of these appeals succeeded, however. ${ }^{64}$ At a minimum, this indicates that, without the right to silence and a broader supportive environment, the accused may be forced to confess at the pre-trial stages to obtain sentencing concessions. The risk of making the police misconduct "essentially invisible" is high. When the accused no longer challenges the legality of investigation, the exclusionary rule becomes pale.

\section{B. Derivative Evidence and Motivational Incentives}

Article 69(7) of the ICC Statute does not address the question of derivative or secondary evidence. Mere exclusion of evidence obtained directly by illegal means is only of symbolic value if additional evidence derived from such evidence is admissible. Under the reliability and integrity rationales adopted in Article 69(7), the admissibility of derivative evidence at the ICC tribunals must be determined on a case-by-case basis, and, on the whole, the test is the same as primary evidence. ${ }^{65}$

In China, the 2012 revision to the CPL does not address the question, either. Specifically, the problem of derivative evidence has two dimensions. The first one

\footnotetext{
63 C. Steiker, Gideon's Problematic Promise, 143 Dadalus 51-61 (2014).

64 These cases are part of my research project on the topic of appellate proceedings of the fast-track sentencing procedure, China Judgments Online [中国裁判文书网], https://wenshu.court.gov.cn.

65 P. Viebig, Illicitly Obtained Evidence at the International Criminal Court 217-9 (2016).
} 
is the "fruit of poisonous tree" doctrine. Much has been discussed the absence of this doctrine in China. It reflects a programmatic compromise: if prosecuting crimes successfully, real evidence derived from coerced confessions shall be admissible.

The second and more complex dimension is the admissibility of repeated confessions. One suspect is usually interrogated repeatedly prior to trial. When the first confession is tainted by a violation and must be excluded, the question arises whether the subsequent confessions shall also be excluded. The issue of the admissibility of repeated confessions was not regulated until the 2017 Exclusionary Rule. Article 5(1) of the Rule stipulates that repeated confessions made by the same accused due to the impact of a previous confession extracted by torture and that are identical with that confession shall be excluded together. At first glance, repeated confessions appear subject to automatic exclusion. But, in comparison with Article 56 of 2018 CPL, which demands exclusion of confessions extracted by torture and other illegal means, Article 5(1) actually narrows down the scope of exclusion. One previous confession obtained by other illegal means, such as threats, deceit, and enticement, does not trigger the exclusion of repeated confessions. Worse still, it is difficult to tell whether repeated confessions result from the impact of the previous extraction of confession by torture. The lingering compulsion inherent in an accused's having let the "cat out of the bag" also requires suppression. ${ }^{66}$

Article 5(2) denies explicitly the notion of automatic exclusion, and sets up an exception to the general requirement of Article 5(1), stipulating that: "If the interrogator is changed and the newly-involved interrogator notifies the accused of rights and legal consequences for confessing at the time of re-interrogation, the accused's voluntary confessions subsequent to notification shall not be excluded." According to my case studies based on China Judgments Online, ${ }^{67}$ only in four cases have the repeated confessions been excluded so far pursuant to Article 5(1). In the overwhelming majority of cases, the courts have confirmed the voluntariness of repeated confessions as long as the newly-involved interrogator has notified the accused of his/her rights and the consequences of providing confession. The notification obligation, which is obviously easy to perform, bespeaks a lower threshold for admitting repeated confessions. Again, this reflects the importance of evidentiary reliability underlying China's exclusionary rule. ${ }^{68}$ Excluding the first illegally obtained confession has already shown a positive response to a

66 Missouri v. Seibert, supra note 33, at 627.

67 China Judgements Online [中国裁判文书网], https://wenshu.court.gov.cn.

68 Luye Mou, China's Exclusionary Rules of Repeated Confessions [论重复供述的排除规则], 6 JURIS [法学家] 127-41 (2019). 
private resort for remedy, as well as the broad public concerns about human rights. Repeated confessions are not the direct products of torture, so that they may not enough blameworthy as is the first confession. Judges are inclined to admit repeated confession to meet the "standard of proof for conviction," which is extremely high in China: the facts are clear, the evidence is hard and sufficient. ${ }^{69}$ When reliable and truthful repeated confessions are admitted instrumentally to secure a conviction, the incentive of obtaining them by any means is still present.

\section{Evidentiary Evaluation and Power Arrangements}

A law of evidence undergirded by atomistic assumptions interferes with fact-finders' evaluation of evidence much more than that resting on holistic premises. ${ }^{70}$ Atomism requires that fact-finders pay no attention to certain information, as expressed by the exclusionary rule. Approaches of evaluating evidence relates closely to the structure of fact-finding. Under a unitary trial structure, when a panel of judges determine both the admissibility and the fact-finding, it is questionable whether they can "unbite the apple" after taking account of the disputed evidence.

In one well-known study, Bernd Schünemann demonstrates the German judges' inability to ignore the evidence that they have already seen. ${ }^{71}$ In American non-jury trials, psychological experiments have shown that judges have difficulty in disregarding inadmissible information. ${ }^{72}$ At the international tribunals, Peter Murphy, once worked as a defense lawyer at the ICTY for a number of years, humbly questions his own ability of sifting through hundreds of speculative hearsay statements, and thus welcomes some form of more structured protection against risk of exposure to perjured or fabricated evidence. ${ }^{73}$

Chinese judges are following a holistic approach to review the legality of disputed evidence, and empirical studies have shown that judges may become prejudiced after reading dossiers before trial. ${ }^{74}$ The psychological phenomenon of coherence shift can strengthen an unwarranted assumption of admissibility and add obstacles

692018 CPL art. 200.

70 M. Damaška, Atomistic and Holistic Evaluation of Evidence: A Comparative View, in Comparative and Private INTERNATIONAL LAW 91-104 (D. Clark ed., 1990).

71 JACKSON \& Summers, supra note 12, at 73-4.

72 A. Wistrich, C. Guthie \& J. Rachlinski, Can Judges Ignore Inadmissible Information, 153 U. PA. L. Rev. 1251-346 (2004-05).

73 P. Murphy, Excluding Justice or Facilitating Justice?, 12 InT'L J. EVIDENCE \& Proof 1-31 (2008).

74 Luye Mou, Atomism or Holism: Evidential Evaluation in China's Exclusionary Rule of Illegally Obtained Evidence, 5 PekING U. L. J. 361-6 (2017). 
to suppress evidence. ${ }^{75}$ Whether judges can arrive at an accurate verdict by "unbiting the apple" remains an empirical question whose answer hinges upon the character of psychological operation that needs further exploration.

What appears clear now is that, under a unitary trial structure in Chinese courtrooms, a mandate of disregarding probative information could become an invitation to hypocrisy: judges might deceive themselves into thinking that they have neglected information that actually influenced their thinking. The best way to prevent inadmissible information from influencing fact-finders is to shield them from it altogether and to invite one independent panel to engage in matters of the admissibility/exclusion of evidence at the time when the evidence is submitted. This calls for structural reforms combining the pre-trail with trial arrangements as a whole.

\section{Exclusionary Discretion and Individual Disposition}

One senior judge from the SPC confesses frankly that he prefers rule to discretion. This is especially true in the criminal trials, as indicated by the ostensible categorical exclusion in Article 56(1) of CPL. Critical reasons for refusing discretion lie in the fact that Chinese judges are reluctant to acquit the accused and scared of reaching a judgment that turns out to be wrongful. More importantly, that is also demanded by the CCP's political campaign for curtailing local discretion and preventing judicial corruption at the local level. As part of a tight framework of law, the 2015 Judicial Accountability Regulation stipulates that judges shall be liable for their performance of trial duties and assume lifelong responsibility for the quality of case handling within the scope of their duties. ${ }^{76}$

The strictest accountability requirement forces them to embrace clear and explicit guidance of rule, rather than discretion that may put themselves into controversial and dangerous situations. One acquittal or wrongful conviction will ruin their careers. Nonetheless, rule can never cope with the infinite variety and detail of the concrete situations, and discretion features in some way at any version of the exclusionary rule. ${ }^{77}$ Critical in this regard are the selection of personnel and the exercise of discretion. This calls for judges' own interpretations of law and specific facts in individual cases. To hold otherwise is to deny the nature of human's decision-making

75 D. Simon, A Third View of the Black Box: Cognitive Coherence in Legal Decision Making, 71 U. CHI. L. Rev. 511-86 (2004).

76 Several Opinions of the Supreme People's Court on Improving the Judicial Accountability System of People's Courts [最高人民法院关于完善人民法院司法责任制的若干意见] (promulgated by the SPC, Sept. 21, 2015), art. 25.

77 Ashworth \& Redmayne, supra note 22, at 357. 
process, not an honest policy for guiding the exercise of discretion in a proper way.

\section{Conclusion and Suggestions}

Procedural and evidentiary features cannot be simply cut and pasted between legal systems. ${ }^{78}$ We must keep alert to the ignorance of those who are to prescribe for Chinese criminal justice system without first taking the trouble to consider basic issues of our practical experience, institutional structure, and political powers. A better scheme of reform is to first acquaint ourselves with domestic issues as well as foreign models in detail, and then consider creatively the possibilities it conditions, constrains, and enables. The topic of illegally obtained evidence, both in the ICC and China, is too complex to find a silver bullet. What is called for here is a re-examination of existing rule and practices in China, using the ICC as a point of perspective and leverage. This comparative study invites several conclusions and preliminary suggestions.

Firstly, the evidence law should be framed in a way that keeps consonant with the institutional environment of one jurisdiction. The process of incorporating one rule will not yield much unless it is more methodical and thoughtful than random shopping. When drafting the ICC Statute and the Rules, the drafters specifically sought not to reproduce local or national models. ${ }^{79}$ Instead, they chose a set of relaxed evidence rule that was conducive to collect evidence and accelerate the proceedings at the ad hoc tribunals. Now that China has incorporated the exclusionary rule, it becomes necessary to legalize the right to silence and its enforcement mechanism, for the sake of protecting the accused from the police's coercion, threat, enticement, and other illegal interrogations. Ex ante prevention is no less important than ex post remedy afforded by the exclusionary rule. Also, experience has shown that the success of most reforms depends on rather the institutional context in which justice is administrated in a particular jurisdiction, than on reformers who like to think on the excellence of rules. ${ }^{80}$ As such, the exclusionary rule is not the end, but the beginning of a series of reform efforts that shall go toward to a liberalized criminal jurisprudence with constitutional and human rights dimensions.

Secondly, the truth-seeking objective must be balanced with other rationales 
of exclusion. The ICC Statute and China's legislation both present promising opportunities for developing a rejuvenated the mechanism of exclusionary rule. Particularly in China, evidence law has undergone rapid doctrinal developments, though it remains somewhat deficient in local suitability and professional credibility. Without a set of clear, coherent, and normatively defensible justifications for exclusion, it is impossible to secure a foothold for the legal-technical analysis of many aspects of rule-making and its enforcement. Given that reliability and accuracy are important, the key question is how to reconcile them with other rationales. The ICC Statute seeks to achieve two objectives (reliability and integrity), which can inform judges to make case-sensitive inquiries necessary to reach a justifiable tradeoff between competing values. Conversely, disguising a preference for reliability and truth under the straightjacket of categorical exclusion, ${ }^{81}$ China aims to eradicate discretion in the process of devising and using the rule. The hard reality is that judges have to exercise de facto discretion to determine whether to admit or exclude certain evidence. As to the deterrent effect, the exclusionary rule may influence police conduct, not by punishing, but by removing the incentive of law-breaking. It is valued instrumentally as a way to securing greater respect for rights in future investigations. ${ }^{82}$ Consequently, we can expect the exclusionary rule to exert educative influence through long-term guidance and habit formation. In short, diverse values embodied in these rationales of exclusion, such as reliability, integrity, and deterrence, are likely to be better served by firm and explicit adherence to principles than by standing on political imperatives or rigid rules.

Thirdly, we must pay due attention to the active role of judges in both the application of exclusionary rule and the broader process of legal transplantation. Translating the aspirations of legal transplant and rationales of evidentiary exclusion into practical decision-making depends no less on the quality, experience, and training of judges than on procedural legislation and normative standards. The exclusionary discretion conferred on judges is highly contextual, particularistic, and fact-sensitive. We can formulate guidelines for its exercise, but cannot anticipate all the possible circumstances to which the rules or guidelines might be applicable.

Laws are written mandates, while those responsible for enforcing them are humans who are at times limited to physical and mental frailty. ${ }^{83}$ An obvious example is that judges are unable to ignore probative information even if the evidence has been excluded. Therefore, training programs must be instituted, so that the personnel

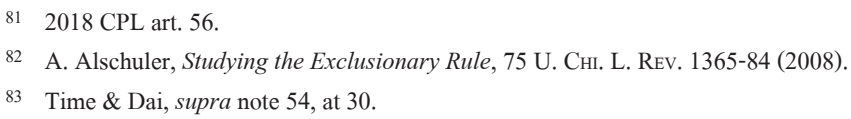


involved in the criminal proceedings, above all police officers, can learn how to work not only with the letters but also with the spirit of the reformed law. Since structural changes are emergent properties that result from the recurring, re-iterative actions of the actors who occupy the social space in question, ${ }^{84}$ the consciousness and experience of legal actors are key elements to the production of change and the reproduction of routine. As a result, I deem it problematic to rely heavily on the accountability mechanism to force judges to implement the rule designed by the toplevel leadership. Rather, attention must be directed to the legal actors' training and ethical orientation that are indispensable not only for using the rule but for shaping the entire criminal justice landscape in a long period of time.

The final reflection focuses on the experiment-based policy process and legal development. Alex Whiting finds that the experimentation has been essential to the development of the international criminal proceedings. ${ }^{85}$ Sebastian Heilmann employs the term, "experimentation under hierarchy," to capture the oscillating dynamics of China's policy-making process. ${ }^{86}$ Recent decades have also witnessed the experimentation as an important component of successful law reforms and an essential part of efforts to localize new rules in China. In this sense, the ability to experiment and learn from practice has brought the ICC and China's laws closer to a model that has no ex ante assumption of celebrated procedural practice in other jurisdictions. Rather, it can make both the ICC and China better achieve their own goals and account for the limitations of evidentiary transplant in the era of globalization. 